\title{
Social Sustainability Adoption Barriers in Supply Chains: A Middle East Perspective using Interpretive Structural Modeling
}

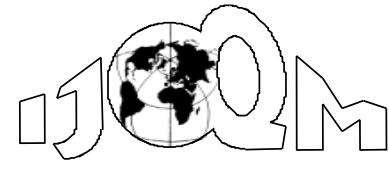

DOI: $10.46970 / 2021.27 .1 .4$

Volume 27, Number 1

March 2021, pp. 61-80
Saheim K. Josaiman

Mohd. Nishat Faisal

Qatar University

(sbk@sbkgroup.net)

(nishat786@qu.edu.qa)

Faisal Talib

Aligarh Muslim University

(ftalib77@gmail.com)

The research in the area of social responsibility in supply chains in the Middle East is limited in the extant literature. The present study tries to fill this gap by identifying and analysing the interactions among the variables that inhibit the implementation of social responsibility practices in supply chains. This researchutilizes Interpretive Structural Modelling and MICM AC approach to establish hierarchical linkages among the identified variables of social sustainability in supply chains. In this research work, thirteen variables were identified based on extensive literature review, which were refined further by brainstorming and experts' opinion. The results indicate that differences in culture and regulatory environment and lack of support from the government and top management are the most important barriers. Social sustainability is an emerging area in the developing economies. This study is among the few that provide an understanding of barriers to social responsibility adoption in supply chains in the Middle East region.

Keywords: Social Sustainability, Supply Chain Management, Middle East, Interpretive Structural Modelling

\section{Introduction}

Social sustainability is the third facet of the Triple Bottom Line (3BL) alongside environmental sustainability and economic sustainability. Social sustainability focuses on the impacts that business operations have on human-related factors, both, within the company and the society. Gnansounou and Pandey (2017) defined several key aspects of social sustainability, namely social wellbeing, social acceptability, training and development, energy security and resource conservation. Supply chain is one of the areas of business operations that involves people, both within a firm and in the downstream and upstream partners in the supply chain, as well as those involved with logistics and transport (Kasonde and Steele, 2017). Thus, in order to ensure social sustainability in business operations, firms need to look at their supply chains in order to improve their performance (Mani et al. 2018; Chiappeta Jabbour and de Sousa Jabbour, 2016).

However, the process of ensuring social sustainability throughout the supply chain is not easy and it faces many barriers. In light of such difficulties, researchers have 
begun to pay attention to the barriers to social sustainability in the supply chain so that these barriers can be understood and therefore addressed (Mani et al., 2018; Awan et al. 2019). However, few studies, if any, have considered the barriers to social sustainability in the supply chain facing firms in Qatar or in the Middle East in general. Therefore, this paper sought to fill this gap in the literature, the major objectives can be stated as:

- identify barriers to social sustainability in the supply chain in through comprehensive literature review;

- establish the interrelationship among identified barriers using ISM-MICMAC approach; and

- address the managerial implications of the current research work

\section{Literature Review: Identification of Barriers}

In the literature on SSCM, a number of barriers can be identified. These can be divided into five main categories: internal barriers, supply chain partner issues, communication issues, financial barriers and other barriers.

\subsection{Internal Barriers}

Three internal barriers were identified in the literature as follows:

- Lack of management support or priorities for socially sustainable practices.

- Dearth of internal programs providing encouragement and motivation for achieving social sustainability.

- Resistance to change to support socially sustainable supply chain.

Lack of support for adopting, implementing or prioritizing socially sustainable SSCM practices is often discussed in the literature in terms of a lack of management commitment (Balon et al. 2016). Oelze (2017) stated that management often did not choose to implement such practices because they had other priorities, that the management was not committed to social sustainability or that they forgot to prioritize this aspect of supply chain when developing their strategies. Tummala et al. (2006) also stated that managers often chose to allocate resources to aspects of their business operations in a way that did not support the adoption of social responsibility practices. This barrier is likely to be highly significant when resources are limited, as suggested by Biswal et al. (2017).

Lack of commitment and support on the part of the management is closely linked to lack of internal programs that provide encouragement and motivation (Awan et al., 201p); Delmonico et al., 2018). In practical terms, this barrier implies that employees may not be willing to implement socially sustainable supply chain practices because they do not have any motivation and will not be rewarded, leading to low employee involvement (Vimal et al., 2019). Tay et al. (2015) indicated that implementing socially sustainable practices may be costly, that include the reward system that encourages employees to carry out their duties in a socially sustainable way.

This barrier was identified as one of the most important ones by Awan et al. (2019), who stated that resistance to adopting new practices often hindered the adoption of "new" socially sustainable supply chain. This resistance to change was also found to be a major barrier to the adoption of socially sustainable supply chain 
by Balon et al. (2016) in their study of supply chains in the automobile industry in India. In a study of sustainable supply chain management practices, Shibkinetet al. (2016) identified a risk-averse attitude as being one of the explanations why management are resistant to change and adopt new practices.

\subsection{Supply Chain Partner Barriers}

Supplier performance in the area of social sustainability affects the social sustainability of a company, as noted by Maniet al. (2018). Furthermore, as stated by Galal and Moneim (2016), if one supply chain partner fails to comply with the requirements of social sustainability, this can be viewed as failure of overall supply chain on social responsibility. Three specific barriers hinder the adoption or implementation of socially sustainable practices relating to supply chain partners are as follows:

- Suppliers and supply chain partners are not aware of socially sustainable practices or do not cooperate or comply with socially sustainable practices because it is too expensive.

- Supply chain partners do not have the resources to implement socially sustainable practices.

- There are no criteria that can be used to select socially responsible suppliers.

Suppliers and supply chain partners (e.g. logistics and shipping companies and warehousing facilities) may not be aware of socially sustainable practices, as indicated by Sajjad et al. (2015), Balon et al. (2016) and Shibin et al. (2016). Shibin et al. (2016) also found that supply chain partners might not comply or cooperate in implementing socially sustainable practices. In light of the fact that supply chains in the modern business environment are often international and suppliers and supply chain partners may often be located in developing nations, supply chain partners may find that implementing socially sustainable practices is too expensive, and this may act as a barrier (Busse et al. 2016; Oelze 2017). This specific issue leads to the second barrier to the implementation of socially sustainable practices relating to supply chain partners and suppliers, namely that suppliers may not have the resources needed to adopt socially sustainable practices. This issue of supply chain partners lacking the financial resources to implement sustainable practices has been noted by research into supply chain sustainability in general, such as the study by Olatunji et al. (2019), Busse et al. (2016) and Oelze (2017).

The third barrier to the adoption of socially sustainable practices related to suppliers and supply chain partners is the fact that it can be difficult to find criteria by which to assess the practices of supply chain partners that can be used when selecting or evaluating these partners. Attempts have been made to develop criteria for such evaluations (Hsu et al., 2013), although mainly researchers were considering sustainability in general rather than social sustainability specifically. This lack of criteria could be because the area of social sustainability has only recently gained the attention of researchers (Mani et al., 2018; Awan et al. 2019). Mani et al. (2015) noted that the criteria used by a different company to evaluate the social sustainability of its supply chain partners were different, highlighting the problem of having adequate criteria that can be useful in the selection of supply chain partners. 


\subsection{Communication Barriers}

Oelze (2017) described several different types of problems in the area of communication within the supply chain that can act as barriers to implementing or adopting SSCM practices. The two main barriers relating to communication issues can be summarized as follows

- Unwillingness of chain partners to disclose information.

- Differences in culture and regulatory environment leading to a different definition of social responsibility or they are too distant from the organization.

Oelze (2017), stated that sometimes, supply chain partners may not be willing to disclose information relating to social sustainability not out of a desire to deceive but because they do not see the need to reveal such information. Communication as barrier because of the unwillingness of partners to disclose information is often referred to in the literature as a transparency issue. For example, Kamali et al. (2018) found that transparency issues related to the supply chain were considered to be an area of concern in terms of governance. Similarly, Bubicz et al. (2019) listed transparency and tracing issues to be one of the barriers to achieving social sustainability in the supply chain. Communication in the supply chain can be hindered because of clashes or misunderstandings between cultures or because the supply chain partners are at a considerable distance from the focal organization, as noted by Busse et al. (2016).

\subsection{Financial Barriers}

Organizations may find that financial barriers hinder the adoption or implementation of socially sustainable practices, a factor that is likely to be linked to the management-related barriers. Several barriers relating to financial issues were identified in the literature as described below.

- Implementing socially sustainable practices is too expensive and/or reducing costs is more important.

- An organization's accounting practices do not take the triple bottom line or social sustainability into account.

- International customers do not encourage the implementation of socially sustainable practices.

Several researchers (Walker et al. 2008; Narayanan et al. 2018; Balon et al. 2016) have noted the high cost of implementing or adopting social responsible practices. Oelze (2017) noted that cost was often a barrier to the implementation of sustainable practices in the textile industry in Bangladesh including the cost of auditing and certification. Tay et al. (2015) also noted that cost was a barrier to the implementation of sustainable practices, especially in smaller firms, as noted by Walker and Jones (2012).Walker and Jones (2012) also stated that companies that prioritize the reduction of costs are also less likely to adopt or implement sustainable practices.

Tay et al. (2015) and Walker and Jones (2012) both noted that one of the financial barriers that discourage organizations from adopting social sustainable practices is that accountants may rely on traditional accounting methods, as also noted in an earlier study by Rao and Holt (2005). Awan et al. (2019) stated that the lack of support from international customers could also be a barrier to the adoption or implementation of socially sustainable practices. Consumers want cheaper products 
(Walker and Jones, 2012), which can act as a barrier to implementing socially responsible practices, as these can often be costly, as mentioned above, including the costs of auditing and certification that would allow a company to be seen by customers as socially sustainable (Oelze 2017).

\subsection{Other Barriers}

The literature reveals several other external barriers to implementing or adopting socially responsible practices that are not related to the supply chain partners but to other factors that are mostly outside an organization. These barriers can be summarized as follows:

- It is hard to train people in socially sustainable practices and it is hard to find experts in this area.

- The government does not support socially sustainable practices.

Vimal et al. (2019) also noted that a lack of training could create some of the supply chain partner-related issues, as a lack of training can affect the social sustainability of the supply partners as well as the organization itself. The issue of a lack of training has also been noted in research into environmental sustainability as well as social sustainability (Kaur et al. 2018; Balon et al. 2016).The attitudes, values and legislation provided by governments can also create barriers to implementing socially sustainable practices. Sajjad et al. (2015) stated that a lack of government support formed a barrier to environmentally sustainable practices, and same can be inferred for socially sustainable practices. Aljoghaiman et al. (2019) listed the government as a stakeholder that can have a negative effect on the adoption of sustainable practices. Balon et al. (2016) noted that the lack of support and guidance provided by governments created a barrier in o implementing and adopting sustainable practices. The barriers identified through literature are summarized in Table 1.

\section{Methodology: Interpretive Structural Modeling (ISM) Framework}

In this research work, opinion of the experts and ISM methodology has been utilized to understand the barriers influencing social sustainability implementation in the supply chain. ISM is a qualitative approach developed by Dr. John Nelson Warfield in the year 1973 (Jabeen et al., 2018) whose aim is to identify and summarize various relationships among specific variables of interest (Faisal and Talib, 2017). It is a bilateral learning process where an arrangement of a set of directly associated variables of a given complex problem are arranged as a comprehensive, powerful well organized, systematized hierarchical model know as structured model (Faisal et al., 2019). ISM can accommodate multiple variables in a structured way (Faial and Talib, 2016) and permits to impose order on the complexity of said variables. ISM also suggest use of experts' survey to establish inter-correlations between variables (Singh and Sushil, 2013). The aim behind adopting this approach is to impose order and direction by developing complex relationships among variables (Faisal et al., 2019; Al-Esmael et al., 2019) It assists decision-makers and managers to identify the key variables in the structure. 
Table 1 Barriers to Social Sustainability in Supply Chain

\begin{tabular}{|c|c|c|}
\hline $\begin{array}{l}\text { S. } \\
\text { No. }\end{array}$ & Barrier & References \\
\hline 1. & Lack of top management support & $\begin{array}{l}\text { Balon et al (2016); Oelze (2017); } \\
\text { Vimal et al. (2019) }\end{array}$ \\
\hline 2. & $\begin{array}{l}\text { Lack of internal programs adoption to support } \\
\text { social sustainability }\end{array}$ & $\begin{array}{l}\text { Delmonico et al. (2018); Biswal et al. } \\
\text { (2017) }\end{array}$ \\
\hline 3. & Resistance to change & $\begin{array}{l}\text { Shibkinet et al. (2016); Balon et al. } \\
\text { (2016) }\end{array}$ \\
\hline 4. & Lack of awareness among SC partners & $\begin{array}{l}\text { Sajjad et al. (2015); Shibin et al. } \\
(2016)\end{array}$ \\
\hline 5. & Lack of resources for SC partners & Oelze (2017); Busse et al. (2016) \\
\hline 6. & $\begin{array}{l}\text { Lack of criteria/models for socially sustainable } \\
\text { partner selection }\end{array}$ & Mani et al. (2015), Awan et al. (2019) \\
\hline 7. & $\begin{array}{l}\text { Unwillingness of SC partners to disclose } \\
\text { information }\end{array}$ & $\begin{array}{l}\text { Bubicz et al. (2019); Astill et al. } \\
(2019)\end{array}$ \\
\hline 8. & $\begin{array}{l}\text { Differences in culture and regulatory } \\
\text { environment }\end{array}$ & Mani et al. (2014); Busse et al. (2016) \\
\hline 9. & High implementation costs for SC partners & Narayanan et al. (2018); Oelze (2017) \\
\hline 10. & $\begin{array}{l}\text { Lack of social sustainability consideration in } \\
\text { accounting practices }\end{array}$ & $\begin{array}{l}\text { Tay et al. (2015); Walker and Jones } \\
(2012)\end{array}$ \\
\hline 11. & $\begin{array}{l}\text { Lack of encouragement from international } \\
\text { customers }\end{array}$ & $\begin{array}{l}\text { Walker and Jones (2012); Mani el al } \\
(2018)\end{array}$ \\
\hline 12. & Lack of availability of training programs & $\begin{array}{l}\text { Vimal et al. (2019); Shibin el al. } \\
\text { (2016) }\end{array}$ \\
\hline 13. & Lack of support from the government & $\begin{array}{l}\text { Sajjad et al. (2015); Aljoghaiman et al. } \\
(2019)\end{array}$ \\
\hline
\end{tabular}

To achieve the objectives of the present research (developing a model of barriers to social sustainability and analyzing the interrelationships by employing ISM), a systematic procedure for developing the ISM framework is described below (Faisal and Talib, 2016a; Faisal and Khan, 2016).

- Stage1: The barriers to social sustainability implementation in the supply chain are identified and arranged via rigor review of literature, feedback from academia and industrial experts, and through brainstorming sessions.

- Stage 2: From the identified set of social sustainability barriers, the contextual relationships and interactions were developed in the form of matrix to understand the effect of one barrier over the other and vice-versa.

- Stage 3: A Structural self-interaction matrix (SSIM) of social sustainability barriers is built from the brainstorming sessions reflecting a pair wise relationship between barriers to social sustainability implementation in the supply chain.

- Stage 4: A reach ability matrix is developed from SSIM and the matrix is checked for transitivity. Transitivity represents the indirect relationship and the rule is that if barrier ' $\mathrm{X}$ ' influence barrier ' $\mathrm{Y}$ ' and barrier ' $\mathrm{Y}$ ' affects barrier ' $\mathrm{Z}$ ', then barrier ' $\mathrm{X}$ ' necessarily influences barrier ' $\mathrm{Z}$ '. 
- Stage 5: A final matrix representing reach ability is attained after incorporating the rule of transitivity and is then partitioned into different levels on the basis of driving and dependence power.

- Stage 6: On the basis of relationships obtained in stage 5, a digraph is figured out and then transitivity links are detached.

- Stage 7: The resulting directed graph (or digraph) is transformed into an ISMbased model by restoring barrier nodes with statements.

- Stage 8: Finally, the ISM model obtained in stage 7 is checked for logical inconsistencies and if any, the refinements are done.

\section{Data Collection and Model Development}

To analyze the barriers of social sustainability implementation in the supply chain, 13 barriers were established from the extent literature review. A total of eight experts were selected to form a decision team consisting of four each from academia and industry and were contacted by e-mail and face-to-face interview to explain the concept of social sustainability implementation in the supply chain. From the group of eight experts, only six showed their willingness towards participation in this study. All the six experts chosen were having enough experience (more than ten years) and skills in their domain and are holding high positions like senior supply chain manager, senior social and environmental scientist, and professor from supply chain management (SCM) and operations management area, and general manager (operations). The problem and objectives of this research were discussed in detail with the decision team; the ISM-based modeling approach was then suggested. The ISM methodology depends upon the experts' opinion in establishing the relationships contextual in nature between the identified barriers (Jabeen and Faisal, 2018). Hence, the investigation of contextual relationships among the barriers of social sustainability was done by organizing several brainstorming sessions with the group of experts i.e. decision team. During this exhaustive process, following activities were accomplished:

- Finalization of identified barriers of social sustainability implementation in the supply chain.

- Rating of various barriers identified from literature review as per their importance towards implementation of social sustainability in the supply chain.

- Analyzing the barriers and developing contextual relationships of 'leads to' type between them is chosen meaning that one barrier leads to another barrier (Faisal et al., 2017; Khanam et al., 2015)

\subsection{Structural Self-Interaction Matrix (SSIM) Development}

Based on expert's opinion, SSIM is formulated. As suggested by ISM methodology, four symbols are utilized to symbolize the direction of contextual relationship among barriers 'i' and 'j' (Talib et al., 2011; Faisal, 2015):

- V-Forward relationship: 'i' influence barrier ' $j$ ';

- A-Backward relationship: 'j' influence barrier 'i';

- X-Cross-relationship: 'i' and 'j' influences each other; and

- O-No relationship between 'i' and 'j'. 
On the basis of the above contextual relationships between barriers resulting from brainstorming sessions, SSIM is obtained and given in Table 2.

Table 2 Structural Self-Interaction Matrix (SSIM)

\begin{tabular}{|c|c|c|c|c|c|c|c|c|c|c|c|c|c|}
\hline $\begin{array}{c}\text { Barrier } \\
\text { No. }\end{array}$ & $\begin{array}{c}\text { Barrier to social sustainability } \\
\text { implementation in SC }\end{array}$ & 13 & 12 & 11 & 10 & 9 & 8 & 7 & 6 & 54 & 4 & 3 & 2 \\
\hline B1 & Lack of top management support & A & $\mathrm{O}$ & $\mathrm{O}$ & $\mathrm{X}$ & $\mathrm{V}$ & $\mathrm{O}$ & $\mathrm{V}$ & $\mathrm{x}$ & $\mathrm{V} \mathrm{V}$ & $\mathrm{V}$ & $\mathrm{V}$ & \multirow[t]{2}{*}{$\mathrm{V}$} \\
\hline $\mathrm{B} 2$ & $\begin{array}{l}\text { Lack of internal programs adoption to } \\
\text { support social sustainability }\end{array}$ & $\mathrm{O}$ & $\mathrm{O}$ & $\mathrm{O}$ & $\mathrm{O}$ & $\mathrm{X}$ & $\mathrm{O}$ & $\mathrm{O}$ & $\mathrm{A} \mid \mathrm{A}$ & $\mathrm{A} \mid \mathrm{A}$ & $\mathrm{A}$ & $\mathrm{V}$ & \\
\hline B3 & Resistance to change & A & A & $\mathrm{O}$ & $\mathrm{O}$ & A & A & A & A & $\mathrm{A} A$ & $\mathrm{~A}$ & - & \\
\hline B4 & Lack of awareness among SC partners & A & $\mathrm{V}$ & $\mathrm{O}$ & $\mathrm{O}$ & $\mathrm{V}$ & $\mathrm{O}$ & $\mathrm{X}$ & $\mathrm{A} \mid \mathrm{Y}$ & $\mathrm{X}$ & - & & \\
\hline B5 & Lack of resources for SC partners & A & $\mathrm{O}$ & $\mathrm{O}$ & $\mathrm{O}$ & $\mathrm{O}$ & A & $\mathrm{X}$ & A & - & & & \\
\hline B6 & $\begin{array}{l}\text { Lack of criteria/models for socially } \\
\text { sustainable partner selection }\end{array}$ & A & $\mathrm{O}$ & $\mathrm{O}$ & $\mathrm{X}$ & $\mathrm{V}$ & A & $\mathrm{O}$ & - & & & & \\
\hline B7 & $\begin{array}{l}\text { Unwillingness of SC partners to disclose } \\
\text { information }\end{array}$ & $\mathrm{O}$ & $\mathrm{V}$ & A & A & $\mathrm{O}$ & $\mathrm{O}$ & - & & & & & \\
\hline B8 & $\begin{array}{l}\text { Differences in culture and regulatory } \\
\text { environment }\end{array}$ & $\mathrm{O}$ & $\mathrm{O}$ & $\mathrm{O}$ & $\mathrm{O}$ & $\mathrm{O}$ & - & & & & & & \\
\hline B9 & $\begin{array}{l}\text { High implementation costs for SC } \\
\text { partners }\end{array}$ & A & $\mathrm{O}$ & $\mathrm{O}$ & $\mathrm{O}$ & - & & & & & & & \\
\hline B10 & $\begin{array}{l}\text { Lack of social sustainability consideration } \\
\text { in accounting practices }\end{array}$ & A & $\mathrm{V}$ & A & - & & & & & & & & \\
\hline B11 & $\begin{array}{l}\text { Lack of encouragement from } \\
\text { international customers }\end{array}$ & $\mathrm{O}$ & $\mathrm{V}$ & - & & & & & & & & & \\
\hline B12 & Lack of availability of training programs & $\mathrm{O}$ & - & & & & & & & & & & \\
\hline B13 & Lack of support from the government & - & & & & & & & & & & & \\
\hline
\end{tabular}

\subsection{Establishment of initial Reach Ability Matrix}

The SSIM (Table 2) is converted into initial reach ability matrix by transforming information into binary numbers ' 0 ' and ' 1 '. The rules followed for conversion are:

- whenever the cell $(i, j)$ is assigned with symbol ' $V$ ', then place ' 1 ' in the $(i, j)$ cell and ' 0 ' in the $(\mathrm{j}, \mathrm{i})$ cell;

- whenever the cell $(i, j)$ is assigned with symbol ' $A$ ', then place ' 0 ' in the $(i, j)$ cell and ' 1 ' in the $(\mathrm{j}, \mathrm{i})$ cell;

- whenever the cell $(i, j)$ is assigned with symbol ' $X$ ', then place ' 1 ' in both the cells $(i, j)$ and $(j, i)$; and

- Whenever the cell $(\mathrm{i}, \mathrm{j})$ is assigned with symbol 'O', then place ' 0 ' in both the cells $(i, j)$ and $(j, i)$.

\subsection{Establishment of Final Reach Ability Matrix}

In the initial reach ability matrix, some cells have ' 0 ' values which are changed by ' 1 ' using transitivity rule, as explained in stage 4 . The replaced value is designated by a 
symbol $1^{\dagger}$. After incorporating the transitivity, the final reach ability matrix looks like as shown in Table 3. The driving power and dependence of each barrier are also calculated from the final reach ability matrix. Dependence power is obtained by adding the number of barriers (including itself) which help to affect it while the driving power of the barriers is equal to the total number of barriers (including itself) which help to affect it. Finally, the ranking of barriers, the number of relationships (81 in this case), and the driving and dependence powers were obtained and are depicted in Table 3 .

Table 3 Final Reach Ability Matrix

\begin{tabular}{|c|c|c|c|c|c|c|c|c|c|c|c|c|c|c|c|}
\hline $\begin{array}{l}\text { Barrier } \\
\text { No. }\end{array}$ & \begin{tabular}{|c|}
$\begin{array}{c}\text { Barrier to social sustainability } \\
\text { implementation in SC }\end{array}$ \\
\end{tabular} & 1 & 2 & 3 & $4:$ & 5 & 6 & & 89 & & 11 & & & $\begin{array}{l}\text { Driving } \\
\text { Power }\end{array}$ & Rank \\
\hline B1 & $\begin{array}{l}\text { Lack of top management } \\
\text { support }\end{array}$ & 1 & 1 & 1 & 1 & 1 & 1 & 10 & \begin{tabular}{l|l|l}
0 & 1
\end{tabular} & 1 & 0 & $1^{\dagger}$ & 0 & 10 & I \\
\hline B2 & $\begin{array}{l}\text { Lack of internal programs } \\
\text { adoption to support social } \\
\text { sustainability }\end{array}$ & 0 & 1 & 1 & $0 \mid$ & 0 & 0 & 0 & \begin{tabular}{l|l|l}
0 & 1
\end{tabular} & 0 & 0 & 0 & 0 & 3 & VI \\
\hline B3 & Resistance to change & 0 & 0 & 1 & 0 & 0 & 0 & \begin{tabular}{l|l}
0 & 0
\end{tabular} & \begin{tabular}{l|l}
0 & 0
\end{tabular} & 0 & 0 & 0 & 0 & 1 & VIII \\
\hline B4 & $\begin{array}{l}\text { Lack of awareness among SC } \\
\text { partners }\end{array}$ & 0 & 1 & 1 & 1 & 1 & 0 & 10 & \begin{tabular}{l|l|l}
0 & 1
\end{tabular} & 0 & 0 & 1 & 0 & 7 & III \\
\hline B5 & $\begin{array}{l}\text { Lack of resources for SC } \\
\text { partners }\end{array}$ & 0 & 1 & 1 & 1 & 1 & 0 & 10 & $01^{\dagger}$ & 0 & 0 & $1^{\dagger}$ & 0 & 7 & III \\
\hline B6 & $\begin{array}{l}\text { Lack of criteria/models for } \\
\text { socially sustainable partner } \\
\text { selection }\end{array}$ & 1 & 1 & 1 & 1 & 1 & 1 & $1^{\dagger} 0$ & 0.1 & 1 & 0 & 0 & 0 & 9 & II \\
\hline B7 & $\begin{array}{l}\text { Unwillingness of SC partners to } \\
\text { disclose information }\end{array}$ & 0 & 0 & 1 & 1 & 1 & 0 & 10 & 00 & 0 & 0 & 1 & 0 & 5 & V \\
\hline B8 & $\begin{array}{l}\text { Differences in culture and } \\
\text { regulatory environment }\end{array}$ & $1^{\dagger}$ & $1^{\dagger}$ & 1 & $1^{\dagger}$ & 1 & 1 & & 10 & $1^{\dagger}$ & 0 & 0 & 0 & 9 & II \\
\hline B9 & $\begin{array}{l}\text { High implementation costs for } \\
\text { SC partners }\end{array}$ & 0 & 1 & 1 & 0 & 0 & 0 & \begin{tabular}{l|l}
0 & 0 \\
0
\end{tabular} & 0.1 & 0 & 0 & 0 & 0 & 3 & VI \\
\hline B10 & $\begin{array}{l}\text { Lack of social sustainability } \\
\text { consideration in accounting } \\
\text { practices }\end{array}$ & 1 & 0 & $1^{\dagger}$ & $1^{\dagger}$ & 1 & 1 & 10 & $01^{\dagger}$ & 1 & 0 & 1 & 0 & 9 & II \\
\hline B11 & $\begin{array}{l}\text { Lack of encouragement from } \\
\text { international customers }\end{array}$ & $1^{\dagger}$ & 0 & $1^{\dagger}$ & & 0 & 0 & 10 & 00 & 1 & 1 & 1 & 0 & 6 & IV \\
\hline B12 & $\begin{array}{l}\text { Lack of availability of training } \\
\text { programs }\end{array}$ & 0 & 0 & 1 & 0 & 0 & 0 & \begin{tabular}{l|l}
0 & 0 \\
0
\end{tabular} & 00 & 0 & 0 & 1 & 0 & 2 & VII \\
\hline B13 & $\begin{array}{l}\text { Lack of support from the } \\
\text { government }\end{array}$ & 1 & & 1 & 1 & 1 & 1 & \begin{tabular}{l|l}
0 & 0
\end{tabular} & $\begin{array}{lll}0 & 1\end{array}$ & 1 & 0 & $1^{\dagger}$ & 1 & 10 & I \\
\hline & Dependence Power & 6 & 8 & 13 & 8 & 8 & 5 & \begin{tabular}{l|l}
8 & 1
\end{tabular} & 18 & 6 & 1 & 8 & 1 & 81 & \\
\hline & Rank & III & II & 1 & 11 & 111 & $v 1$ & II $\mathrm{V}$ & $\mathrm{v} / 11$ & $\Pi$ & $\mathrm{V}$ & II & V & & \\
\hline
\end{tabular}

Note: I'Entries are Included to Incorporate Transitivity.

\subsection{Level Partitioning of the Barriers}

The different ISM model levels are obtained by finding the reach ability set, antecedent set, and interaction set using final reach ability matrix. A reach ability set for a particular barrier comprises the barrier itself and all those barriers which it may help to hold. The antecedent set for a particular barrier includes the barrier itself and 
those barriers which may reduce them. From these two sets, an interaction set is formed, which contains common barriers in the reach ability and antecedent sets. Those barriers whose reach ability set and the antecedent set are the same will be placed at the top level in the ISM hierarchy (Dubey et al., 2015). Immediately after first iteration is completed, this barrier is termed as Level-I and is removed (Table 4). The same procedure is replicated to the remaining barriers and determines the second level barriers (Level-II) which is positioned at second place from the top. In the same manner, the other levels are assessed until each level of every barrier is determined (Table 5). From Table 5, it is clear that 'resistance to change (B3)' is identified at Level-I (top level).

Table 4 Barriers of Social Sustainability in SC-Level I-Iteration i

\begin{tabular}{|c|c|c|c|c|}
\hline $\begin{array}{l}\text { Barrier } \\
\text { (Bi) }\end{array}$ & Reachability set $\mathbf{R}(\mathbf{B i})$ & Antecedent set A (Bi) & $\begin{array}{c}\text { Intersection set } \\
\mathbf{R}(\mathbf{B i}) \cap \mathbf{A}(\mathbf{B i})\end{array}$ & Level \\
\hline B1 & $\begin{array}{l}\text { B1, B2, B3, B4, B5, B6, } \\
\text { B7, B9, B10, B12 }\end{array}$ & $\mathrm{B} 1, \mathrm{~B} 6, \mathrm{~B} 8, \mathrm{~B} 10, \mathrm{~B} 11, \mathrm{~B} 13$ & & \\
\hline B2 & B2, B3, B9 & $\begin{array}{l}\text { B1, B2, B4, B5, B6, B8, B9, } \\
\text { B13 }\end{array}$ & & \\
\hline B3 & B3 & $\begin{array}{l}\text { B1, B2, B3, B4, B5, B6, B7, } \\
\text { B8, B9, B10, B11, B12, B13 }\end{array}$ & B3 & I \\
\hline B4 & $\begin{array}{l}\text { B2, B3, B4, B5, B7, B9, } \\
\text { B12 }\end{array}$ & $\begin{array}{l}\text { B1, B4, B5, B6, B7, B8, B10, } \\
\text { B13 }\end{array}$ & & \\
\hline B5 & $\begin{array}{l}\text { B2, B3, B4, B5, B7, B9, } \\
\text { B12 }\end{array}$ & $\begin{array}{l}\text { B1, B4, B5, B6, B7, B8, B10, } \\
\text { B13 }\end{array}$ & & \\
\hline B6 & $\begin{array}{l}\text { B1, B2, B3, B4, B5, B6, } \\
\text { B7, B9, B10 }\end{array}$ & $\mathrm{B} 1, \mathrm{~B} 6, \mathrm{~B} 8, \mathrm{~B} 10, \mathrm{~B} 13$ & & \\
\hline B7 & $\mathrm{B} 3, \mathrm{~B} 4, \mathrm{~B} 5, \mathrm{~B} 7, \mathrm{~B} 12$ & $\begin{array}{l}\text { B1, B4, B5, B6, B7, B8, B10, } \\
\text { B11 }\end{array}$ & & \\
\hline B8 & $\begin{array}{l}\text { B1, B2, B3, B4, B5, B6, } \\
\text { B7, B8, B10 }\end{array}$ & B8 & & \\
\hline B9 & $\mathrm{B} 2, \mathrm{~B} 3, \mathrm{~B} 9$ & $\begin{array}{l}\text { B1, B2, B4, B5, B6, B9, B10, } \\
\text { B13 }\end{array}$ & & \\
\hline B10 & $\begin{array}{l}\text { B1, B3, B4, B5, B6, B7, } \\
\text { B9, B10, B12 }\end{array}$ & $\mathrm{B} 1, \mathrm{~B} 6, \mathrm{~B} 8, \mathrm{~B} 10, \mathrm{~B} 11, \mathrm{~B} 13$ & & \\
\hline B11 & $\begin{array}{l}\text { B1, B3, B7, B10, B11, } \\
\text { B12 }\end{array}$ & B11 & & \\
\hline B12 & B3, B12 & $\begin{array}{l}\text { B1, B4, B5, B7, B10, B11, } \\
\text { B12, B13 }\end{array}$ & & \\
\hline B13 & $\begin{array}{l}\text { B1, B2, B3, B4, B5, B6, } \\
\text { B9, B10, B12, B13 }\end{array}$ & B13 & & \\
\hline
\end{tabular}

\subsection{Digraph and ISM Model}

From the final reach ability matrix, a digraph is constructed that includes transitivity links. The digraph constitutes a set of nodes (barriers) which are connected together on the basis of their relationships in the matrix. Further, the links connecting these nodes are represented by arrows specifying the direction from one node to the other (Faisal, 2010). For example, if barrier 1 affect to barrier 2, then an arrow pointing 
Table 5 Level identification for Each Barrier-Iteration $i$-v

\begin{tabular}{|c|c|l|l|l|c|}
\hline $\begin{array}{c}\text { Barrier } \\
\text { (Bi) }\end{array}$ & Iteration & $\begin{array}{l}\text { Reach ability } \\
\text { set R(Bi) }\end{array}$ & \multicolumn{1}{|c|}{ Antecedent set A (Bi) } & \multicolumn{1}{|c|}{$\begin{array}{c}\text { Intersection set } \\
\mathbf{R}(\mathbf{B i}) \cap \mathbf{A}(\mathbf{B i})\end{array}$} & Level \\
\hline B1 & i & B3 & $\begin{array}{l}\text { B1, B2, B3, B4, B5, B6, B7, } \\
\text { B8, B9, B10, B11, B12, B13 }\end{array}$ & B3 & I \\
\hline B2 & ii & B2, B9 & $\begin{array}{l}\text { B1, B2, B4, B5, B6, B8, B9, } \\
\text { B13 }\end{array}$ & B2, B9 & II \\
\hline B9 & ii & B2, B9 & $\begin{array}{l}\text { B1, B2, B4, B5, B6, B9, B10, } \\
\text { B13 }\end{array}$ & B2, B9 & II \\
\hline B12 & ii & B12 & $\begin{array}{l}\text { B1, B4, B5, B7, B10, B11, } \\
\text { B12, B13 }\end{array}$ & B12 & II \\
\hline B4 & iii & B4, B5, B7 & $\begin{array}{l}\text { B1, B4, B5, B6, B7, B8, B10, } \\
\text { B13 }\end{array}$ & B4, B5, B7 & III \\
\hline B5 & iii & B4, B5, B7 & $\begin{array}{l}\text { B1, B4, B5, B6, B7, B8, B10, } \\
\text { B13 }\end{array}$ & B4, B5, B7 & III \\
\hline B7 & iii & B4, B5, B7 & $\begin{array}{l}\text { B1, B4, B5, B6, B7, B8, B10, } \\
\text { B11 }\end{array}$ & B4, B5, B7 & III \\
\hline B1 & iv & B1, B6, B10 & B1, B6, B8, B10, B11, B13 & B1, B6, B10 & IV \\
\hline B6 & iv & B1, B6, B10 & B1, B6, B8, B10, B13 & B1, B6, B10 & IV \\
\hline B10 & iv & B1, B6, B10 & B1, B6, B8, B10, B11, B13 & B1, B6, B10 & IV \\
\hline B8 & v & B8 & B8 & B8 & V \\
\hline B11 & v & B11 & B13 & B13 & V \\
\hline B13 & v & B13 & V \\
\hline
\end{tabular}

towards 2 from 1 is drawn. If both the barriers affect each other, then a bi-directional arrow is drawn attaching those two barriers. This process give rise to a digraph.

The final digraph generated in previous section is then converted into an ISM model by removing transitivity links and restoring node numbers by corresponding barriers. The proposed ISM model for barriers to social sustainability implementation in the supply chain is obtained as presented in Figure 1.

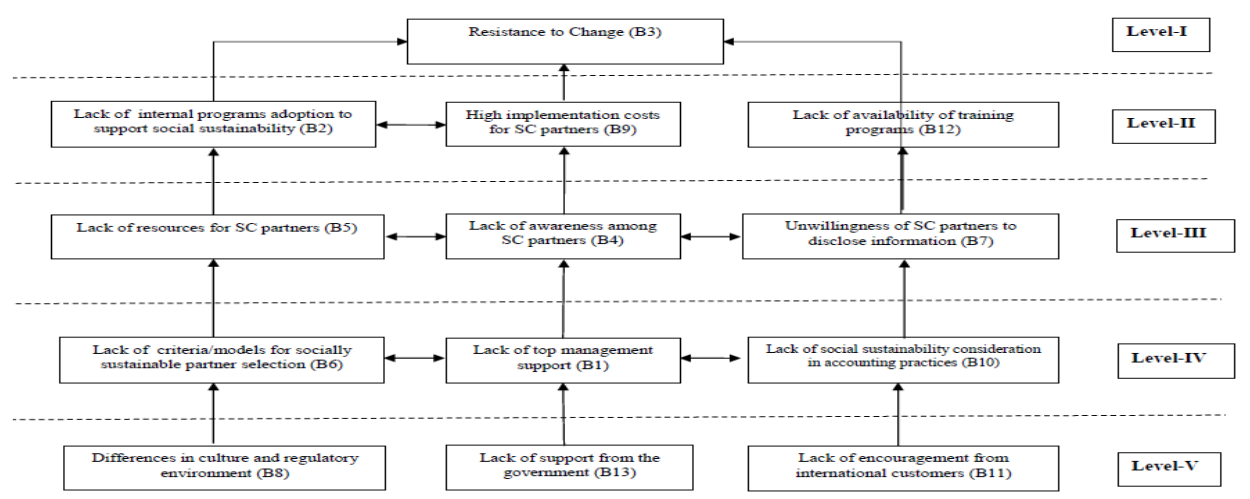

Figure 1 Proposed ISM Model for the Barriers to Social Sustainability Adoption in Supply Chain 
It may be analyzed from Figure 1 that 'difference in culture and regulatory environment (B8)', 'lack of support from the government (B13)' and 'lack of encouragement from international customers (B11)' are most important barriers to social sustainability implementation in the supply chain as they configure the base of the ISM hierarchy. 'Lack of top-management commitment (B1)' and 'Lack of social sustainability practices consideration (B10)' as well as 'Lack of models for social sustainable partner selection (B6)' may be caused by the 'Lack of support from the government (B13), 'Lack of encouragement from international customers (B11)' and 'Differences in culture and regulatory environment (B8)' as evident from the proposed ISM model.

The proposed model can further be classified into three levels of decision hierarchy: namely strategic level, tactical level and operational level. Barriers that have taken position at the bottom falls under operational related barriers that have strongest driving power and are independent barriers. The operational barriers in the present ISM model are: 'Differences in culture and regulatory environment (B8)', 'lack of support from the government (B13)', 'lack of top management support (B1)', 'lack of criteria/models for socially sustainable partner selection (B6)', and 'lack of social sustainability consideration in accounting practices (B10)'. These operational barriers are related to frequently driven actions and have a short-term influence. These barriers are generally taken-up by managers and practitioners. The barriers present at the center of the ISM model are defined as tactical barriers. These barriers are related to tactical decisions generally taken by middle-level managers and supervisors for implementing strategic plans. The tactical barriers in the present model are: 'Lack of awareness among SC partners (B4)' and 'lack of resources for SC partners (B5)'. Finally, the barriers which occupied the top position are strategic and have a long-term effect on the entire system. These barriers have high-dependence and low driving power and are top-management responsibility. In the present model, there are five strategic barriers to social sustainability implementation in the supply chain namely: 'Resistance to change (B3)', 'lack of internal programs adoption to support social sustainability (B2)', 'high implementation costs for SC partners (B9)', 'lack of availability of training programs (B12)', and 'unwillingness of SC partners to disclose information (B7)'.

\subsection{MICMAC Analysis}

MICMAC analysis also referred as cross-impact matrix multiplication applied to classification works on the properties of the multiplication matrices (Dubey et al., 2015), and one of the important properties of this analysis is to determine the level of effect a specific barrier establishes over others and vice-versa (Faisal, 2015). MICMAC analysis is used to get in-depth insights on the barriers to social sustainability implementation in the supply chain by analyzing the strength or shortcomings of driving power and dependence of the barriers under consideration. The driving and dependence power indices for the MICMAC analysis were previously obtained from the Table 5. Accordingly, the barriers to social sustainability implementation are categorized into four stated clusters or quadrants (Faisal and Talib, 2016b; Faisal 2010) with the following features: 
- Cluster I (Quadrant I): This cluster contains 'autonomous barriers' with weak driving and dependence power. 'Lack of encouragement from international customers (B11)' falls in this cluster.

- Cluster II (Quadrant II): This cluster contains 'dependent (driven) barriers' with weak driving and high dependence powers. 'Unwillingness of SC partners to disclose information (B7)', 'lack of internal programs adoption to support social sustainability (B2)', 'high implementation costs for SC partners (B9)', 'lack of availability of training programs (B12)', and 'resistance to change (B3)' are all grouped as dependent barriers.

- Cluster III (Quadrant III): This cluster contains barriers having high driving and dependence powers and are termed as 'linkage barriers'. The barriers that falls in this category are: 'Lack of awareness among SC partners (B4)' and 'lack of resources for SC partners (B5)'.

- Cluster IV (Quadrant IV): This cluster contains 'independent (driving) barriers', which have weak dependence and strong driving power. 'Differences in culture and regulatory environment (B8)', 'lack of support from the government (B13)', 'lack of social sustainability consideration in accounting practices (B10)', 'lack of top management support (B1)', and 'lack of criteria/models for socially sustainable partner selection (B6)' are recognized as the driver barriers.

Based on the driving power and dependence, the classification of barriers to social sustainability adoption in the supply chain presented above may assist in understanding the contribution of barriers and, most importantly, which set of barriers 'influences' or is 'influenced by' other set of barriers. Opinion of experts and researchers suggest that the linkage barriers cluster is closely associated and influenced by the driving barriers cluster, and driving barriers along with linkage barriers clusters will activate dependent barrier's cluster towards improper or deteriorating social sustainability implementation in the supply chain. This display of interdependency and interrelationships between the four clusters of barriers to social sustainability implementation in the supply chains is represented in Figure 2.

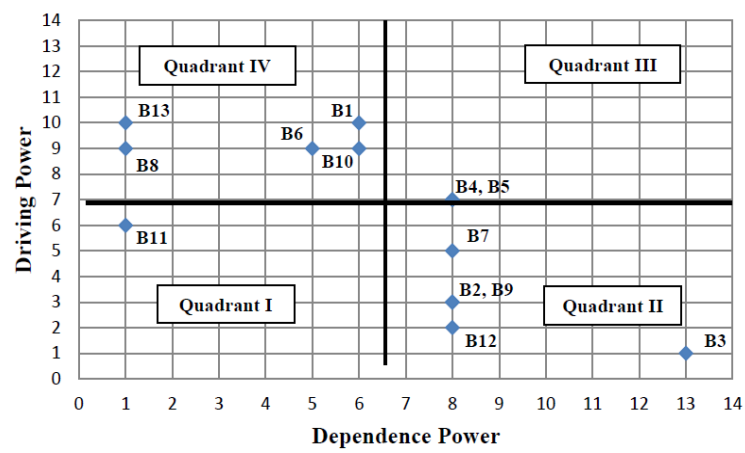

Figure 2 MICMAC Analysis of Barriers to Social Sustainability Adoption in SC

\section{Results and Discussion}

The main aim of this research is to identify and analyze the barriers to social sustainability implementation in the supply chain. After establishing the major 
barriers, one can widen the analysis to different areas of business operations involving supply chain and logistics management with the aim to eliminate or minimize the potentiality of similar barriers. Therefore, attaining the knowledge and clear understanding of various levels of barriers obtained in the form of ISM model is paramount of interest for effective social sustainability implementation in the supply chain. In the current research, a five-level hierarchical model was developed specifying 13 social sustainability barriers in the supply chain through extent literature review and inputs received from industry experts and academia as shown in Figure 1. Barrier 'resistance to change (B3)' is recognized as the top-most barrier placed at Level-Iin the hierarchical model. 'Lack of internal programs adoption to support social sustainability (B2)', 'high implementation costs for SC partners (B9)', and 'lack of availability of training programs (B12)' which are positioned at Level-II in the hierarchy drives the 'resistance to change (B3)' barrier. The top two levels barriers that is 'resistance to change (B3)', 'lack of internal programs adoption to support social sustainability (B2)', 'high implementation costs for SC partners (B9)', and 'lack of availability of training programs (B12)' are observed as least dominant barriers in comparison with other barriers that requires least attention by managers and practitioners to adopt social sustainability in the supply chain. Furthermore, these barriers are driven by another nine barriers, two of which exists at the middlelevel (i.e. Level-III of the ISM hierarchy) viz. 'lack of awareness among SC partners (B4)' and 'lack of resources for SC partners (B5)'. It is noticed from ISM structure that five barriers occupies the bottom levels of the hierarchy (Levels IV and V), these include: 'lack of criteria/models for socially sustainable partner selection (B6), 'lack of top management support (B1)', 'lack of social sustainability consideration in accounting practices (B10)', 'differences in culture and regulatory environment (B8)', and 'lack of support from the government (B13)'. These barriers were considered to have highest driving power and are the most important barriers that influence the connecting barriers in the ISM model. These barriers present at the low levels (Levels IV and V) of the hierarchy in the ISM model needs special attention and should be tackled strategically to implement social sustainability in the supply chain.

MICMAC analysis was further used to provide deeper understanding about the characteristics of the barriers. In this analysis, the barriers are examined with respect to four boundaries build on the basis of driving and dependence powers as shown in Figure 2. The result showed that the barrier 'lack of encouragement from international customers (B11)' lies in the Quadrant I (autonomous) having low driving power and dependence implying that this barrier is detached from the structure and have no effect on the system. The barriers in the Quadrant II (dependent barriers) are the resultant barriers, which have a high dependence power and least influential. In the present research, barriers: 'resistance to change (B3)' barrier. The top two levels barriers that is 'resistance to change (B3)', 'lack of internal programs adoption to support social sustainability (B2)', 'high implementation costs for SC partners (B9)', and 'lack of availability of training programs (B12)', and 'unwillingness of SC partners to disclose information (B7)' have a strong dependence and weak driving powers and are positioned at the top levels (Levels I and II) in the ISM structure, which implies that all the remaining barriers acts as obstacles to social sustainability implementation in the supply chain. Managers, supply chain partners and practitioners should sensibly examine 
characteristics of these dependent barriers as well as their influence on the related barriers during implementation of social sustainability in the supply chain.

The barriers in the Quadrant III (linkage barriers) are also called as relay barriers having strong driving and dependence powers. This cluster contain linkage barriers, which gets influenced and are also influence others in the system. In this research, two barriers fall into this category (Figure 2): 'lack of awareness among SC partners (B4)' and 'lack of resources for SC partners (B5)'. These linkage barriers occupy center position (Level-III) in the hierarchy model. These two linkage barriers suggest that they are the most unstable barriers and managers, supply chain partners and practitioners should handle them carefully while implementing social sustainability in the supply chain.

The barriers in the Quadrant IV (independent barriers) are called as driver barriers and are important with little dependency. These are considered as critical barriers as they independently drive the whole system. The primary objective of managers, supply chain partners and practitioners is to pay attention on these driving barriers and develop a strategical planning on priority basis for social sustainability implementation in the supply chain. In the current research, five barriers fall in cluster IV. They are: 'lack of criteria/models for socially sustainable partner selection (B6), 'Lack of top management support (B1)', 'lack of social sustainability consideration in accounting practices (B10)', 'differences in culture and regulatory environment (B8)', and 'lack of support from the government (B13)'. The present hierarchical model in this research will help managers, supply chain partners, decision makers and practitioners in having a close understanding of the barriers hindering the successful implementation of social sustainability in the supply chain.

\section{Conclusions}

The purpose of this research study is to investigate the interrelationship between 13 identified barriers to social sustainability implementation in the supply chain. The barriers were determined from extensive review of literature and through opinion of experts. To understand the interaction between barriers, a hierarchical model based on ISM methodology was adopted to explore the contextual relationship among the identified barriers. Additionally, the barriers were classified into four clusters based on their driving and dependence powers to perform MICMAC analysis. The main contributions of this research are:

- Identifying the barriers influencing implementation of social sustainability in the supply chain. Though sufficient literature is available on sustainability barriers, but study on understanding the interaction among social sustainability barriers in the supply chain has not been undertaken in a greater way.

- The findings from the present research will assist managers, supply chain partners and practitioners to assess and examine their present position before implementing the social sustainability practices in the supply chain. This will highly beneficial to them to organize their social sustainability strategy.

- Development of contextual relationships among barriers through an ISM modelling approach that may help positioning the barriers at different levels in the developed model. 
- Performing the MICMAC analysis, which helps to classify and rank barriers as per their characteristics and significance in the system and suggest managers, supply chain partners and practitioners to emphasize on the barriers present in the Quadrant IV.

- $\quad$ 'Lack of criteria/models for socially sustainable partner selection (B6), 'lack of top management support (B1)', 'lack of social sustainability consideration in accounting practices (B10)', 'differences in culture and regulatory environment (B8)', and 'lack of support from the government (B13)' are important barriers to successful implementation of social sustainability in the supply chain. These barriers lie at the bottom of the model as they have the strongest driving power and the weakest dependence.

- It may be noted that not only concentrating on the barriers having high driving power, in addition, the barriers having high driving and dependence (linkage barriers) are also equally important to eliminate or minimize the outcome barriers as these barriers are the most unstable which are influential and are also influenced by others in the system.

\subsection{Research Implications}

Based on the outcome of the developed hierarchical model and the inferences obtained from the MICMAC analysis, the following managerial implications can be deduced

- Setting appropriate strategy to social sustainability adoption is necessary for the supply chain managers and partners. However, recognizing the barriers is a prerequisite to social sustainability adoption in supply chain. This study can help managers and practitioners on such aspects by understanding the significant barriers.

- The proposed ISM model can provide managers, supply chain partners and practitioners a more realistic representation and understanding of the social sustainability problem and this will lead to the social concern of the organization.

- Importance of social sustainability concept and practices in the supply chain may be introduced as these concepts provide a way to improve businessperformance by meeting people's social, cultural, emotional, physical, and spiritual needs and win over intense global competition.

- Cross-cultural communication and common regulatory environmental practices together with the support of top-management and government personnel can act as a significant driving force for social sustainability implementation. The present research may motivate managers and supply chain partners in adopting social sustainability practices for the greater benefit of their organization.

- Business organization should support sustainable practices and adopt them in supply chain to achieve social, environmental and economical sustainability at a larger extant. Sustainable practices can minimize energy consumption, waste reduction, safe working environment, resource conservation, and can achieve competitive edge in global business. This work may generate awareness among stakeholders for establishing a newer sustainable supply chain. 


\subsection{Future Scope of the Research}

As with other research, this research also has some limitations and gaps that can be explored by future researchers. In this research, modelling of relationship between the barriers of social sustainability implementation in the supply chain is built without statistically validation. An attempt can be made by future researchers to use Path Modelling Method using variance based Structural Equation Modelling (SEM) or Partial Least Square (PLS) modelling for validating such proposed models. Additionally, ISM is mainly dependent on the judgement of experts, which may be biased as some significant barriers may be missed. Future research can be taken- up to reestablish the model using Total Interpretive Structural Modelling (TISM), which can help for greater degree of conceptualization of related barriers and the theory building.

\section{References}

1. Al-Esmael, B., Talib, F., Faisal, M.N., \& Jabeen, F. (2019). Socially Responsible Supply Chain Management in Small and Medium Enterprises in the GCC. Social Responsibility Journal,16(3), 369-386

2. Aljoghaiman, A., Saad, M., \& Kumar, V. (2019). Investigating the motivators, barriers and enablers associated with the implementation of sustainable supply chain in Saudi manufacturing industry. 3rd IEOM European International Conference on Industrial Engineering and Operations Management, Pilsen, Pilsen, Czech Republic; 23-26 July 2019.

3. Awan U., Khattak A., Kraslawski A. (2019). Corporate Social Responsibility (CSR) Priorities in the Small and Medium Enterprises (SMEs) of the Industrial Sector of Sialkot, Pakistan. In: Golinska-Dawson P., Spychała M. (eds) Corporate Social Responsibility in the Manufacturing and Services Sectors. EcoProduction (Environmental Issues in Logistics and Manufacturing). Springer, Berlin, Heidelberg

4. Balon, V., Sharma, A. K., \& Barua, M. K. (2016). Assessment of barriers in green supply chain management using ISM: a case study of the automobile industry in India. Global Business Review, 17(1), 116-135.

5. Biswal, J.N., Muduli, K. \&Satapathy, S. (2017). Critical analysis of drivers and barriers of sustainable supply chain management in Indian thermal sector. International Journal of Procurement Management, 10(4): 411-430.

6. Bubicz, M.E., Ferreira, A.P., Barbosa-Póvoa, D., \& Carvalho, A. (2019). Incorporating social aspects in sustainable supply chains: Trends and future directions. Journal of Cleaner Production, https://doi.org/10.1016/j.jclepro.2019.06.331

7. Busse, C., Schleper, M.C., Niu, M. \& Wagner, S.M. (2016). Supplier development for sustainability: contextual barriers in global supply chains. International Journal of Physical Distribution \& Logistics Management.46 (5), 442-468.

8. Delmonico, D., Jabbour, C.J.C., Pereira, S.C.F., Jabbour, A.B.L., \&Thomé, A.M.T. (2018). Unveiling barriers to sustainable public procurement in emerging economies: evidence from a leading sustainable supply chain initiative in Latin America. Resources, Conservation and Recycling, 134, 70-79. 
9. Dubey, R., Gunasekaran, A., Sushil \&Singh, T. (2015). Building theory of sustainable manufacturing using total interpretive structural modelling. International Journal of System Science: Operations and Logistics, 2(4), 231247.

10. Faisal, M. N. (2010). Sustainable Supply Chains: A Study of Interaction among the Enablers. Business Process Management Journal, 16(3), 508-529

11. Faisal, M. N. (2015). A Study of Inhibitors to transparency in red meat supply chains in GCC countries. Business Process Management Journal, 21(6), 12991318.

12. Faisal, M. N. \& Khan, H. (2016). A structural analysis of the enablers of ucommerce proliferation in a developing economy", International Journal of Productivity and Performance Management, 65(7), 925-946

13. Faisal, M. N. \& Talib, F. (2016b) Implementing traceability in Indian foodsupply chains: An interpretive structural modeling approach. Journal of Foodservice Business Research, 19(2), 171-196

14. Faisal, M.N. \& Talib, F. (2016a). E-government to m-government: a study in a developing economy", International Journal of Mobile Communications, 14(6), 568-592.

15. Faisal, M.N. \& Talib, F. (2017). Building ambidextrous supply chains in SMEs: How to tackle the barriers? International Journal of Information Systems and Supply Chain Management, 10(4), 80-100.

16. Faisal, M.N., Talib, F., \& Bhutta, M.K. (2019). Enablers of Sustainable Solid Waste Management System in India. International Journal of Environment and Waste Management, 23(3), 213-237.

17. Galal, N.A., Ahmed F. \&Moneim, A. (2016). Developing Sustainable Supply Chains in Developing Countries. Procedia CIRP, 48, 419-424.

18. Gnansounou, E. \& Pandey, A. (2017). Classification of Bio-refineries Taking into Account Sustainability Potentials and Flexibility. In Life-Cycle Assessment of Biorefinerie, 1-39. Elsevier.

19. Hsu, C.-W., Kuo, T.-C., Chen, S.-H. \& Hu, A.H. (2013). Using DEMATEL to develop a carbon management model of supplier selection in green supply chain management. Journal of Cleaner Production, 56(1), 164-172.

20. Jabeen, F. \& Faisal, M.N. (2018). Imperatives for improving entrepreneurial behavior among females in the UAE: An empirical study and structural model. Gender in Management, 33(3), 234-252

21. Jabeen, F., Faisal, M. N., \& Katsioloudes, M.I. (2018). Localisation in an emerging Gulf economy: Understanding the role of education, job attributes and analysing the barriers in its process. Equality, Diversity and Inclusion: An International Journal, 37(2), 151-166

22. Kamali, F.P., Borges, J.A.R., Osseweijer, P., \& Posada, J.A. (2018). Towards social sustainability: Screening potential social and governance issues for bio-jet fuel supply chains in Brazil. Renewable and Sustainable Energy Reviews, 92, 50-61,

23. Kasonde, M. \& Steele, P. (2017). The people factor: An analysis of the human resources landscape for immunization supply chain management. Vaccine, 35(17), 2134-2140. 
24. Kaur, J., Sidhu, R., Awasthi, A., Chauhan, S. \&Goyal, S. (2018). A DEMATEL based approach for investigating barriers in green supply chain management in Canadian manufacturing firms. International Journal of Production Research, 56(1-2), 312-332.

25. Khan, H., Talib, F. \& Faisal, M.N. (2015). An analysis of the barriers to the proliferation of $\mathrm{m}$-commerce in Qatar: a relationship modeling approach. Journal of Systems and Information Technology, 17(1), 54-81.

26. Khanam, S., Talib, F. \& Siddiqui, J. (2015). Identification of TQM enablers and IT resources for ICT industry: a Pareto analysis approach. International Journal of Information Quality, 4(1), 18-41.

27. Mani, V. Agrawal, R., \& Sharma, V. (2015). Supply Chain Social Sustainability: A Comparative Case Analysis in Indian Manufacturing Industries. Procedia - Social and Behavioral Sciences, 189, 234-251.

28. Mani, V., Gunasekaran, A., Papadopoulos, T., Hazen, B., \& Dubey, R. (2016). Supply chain social sustainability for developing nations: evidence from India. Resources, Conservation and Recycling, 111, 42-52.

29. Narayanan, A.E., Sridharan, R. \& Ram Kumar P.N (2018). Analyzing the interactions among barriers of sustainable supply chain management practices. Journal of Manufacturing Technology Management, 30(6), 937-971

30. Oelze, N. (2017). Sustainable supply chain management implementation enablers and barriers in the textile industry. Sustainability, 9(8), 1435

31. Olatunji O. O., Akinlabi, A., Ayo, O.O., Madushele, N., Adedeji, P.A., \&Fatoba, S.O. (2019). Drivers and barriers to competitive carbon footprint reduction in manufacturing supply chain: a brief review. Procedia Manufacturing. 35, 992-1000

32. Rao, P. \& Holt, D. (2005). Do green supply chains lead to competitiveness and economic performance?.International Journal of Operations and Production Management, 25(9), 898-916.

33. Sajjad, A., Eweje, G., \& Tappin, D. (2015). Sustainable supply chain management: motivators and barriers. Business Strategy and the Environment, 24, 643-655.

34. Shibin, K.T., Gunasekaran, A., Papadopoulos, T., Dubey, R., Singh M. \&Wamba, S.F. (2016). Enablers and barriers of flexible green supply chain management: a total interpretive structural modeling approach. Global Journal of Flexible Systems Management, 17, 171-188.

35. Singh, A.K. \&Sushil (2013). Modeling enablers of TQM to improve airline performance. International Journal of Productivity and Performance Management, 62(3), 250-275.

36. Talib, F., Rahman, Z., \& Qureshi, M.N. (2011). Analysis of interaction among the barriers to total quality management implementation using interpretive structural modeling (ISM) approach. Benchmarking: An International Journal, 18(4), 563-587.

37. Tay, M.Y., Rahman, A.A., Aziz, Y.A. \&Sidek, S. (2015). A review on drivers and barriers towards sustainable supply chain practices. International Journal of Social Science and Humanity, 5(10), 892-897. 
38. Tummala, V.M., Phillips, C. \& Johnson, M. (2006). Assessing supply chain management success factors: a case study. Supply Chain Management, 11(2), 179-192.

39. Vimal, K.E.K., Nishal, M. \& Jayakrishna K. (2019). Sustainable supply chain management: Barriers and analysis methods. In M.V. Kumar, G.D. Putnik, K. Jayakrishna, V.M. Pillai \& L. Varela (Eds), Emerging Applications in Supply Chains for Sustainable Business Development (pp. 103-114). Hershey, PA: IGI Global.

40. Walker, H. \& Jones, N. (2012). Sustainable supply chain management across the UK private sector. Supply Chain Management: An International Journal, 17, $15-28$.

41. Walker, H., Sisto, L.D., \&McBain, D. (2008). Drivers and barriers to environmental supply chain management practices: Lessons from the public and private sectors. Journal of Purchasing and Supply Management, 14(1), 69-85.

\section{About Our Authors}

Saheim K Josaiman is working as Academic Director at the College of North Atlantic, Qatar. His work experience is within oil and gas industry where previously he was working as marketing manager in Qatar Petroleum Company. He is also the chairperson and founder of SBK Holding group of companies (since 2003) specialized in construction, real estate, petrochemical factories, logistics services, educational services and trading. He has done his Bachelors in Management and Marketing from Qatar University (Qatar) and MBA from University of Liverpool (UK).

Mohd. Nishat Faisal is a Professor of Supply Chain Management and Performance Excellence at the Department of Management \& Marketing, College of Business \& Economics, Qatar University, Doha, Qatar. His areas of interest are Supply Chain Management, Mathematical Modeling, Performance Excellence, and Sustainability. His research has appeared in publications from Springer, Elsevier, Emerald, Inderscience, Taylor \& Francis among others. His papers on supply chain risk management are listed among the most cited papers of this area. He is also the recipient of Emerald Highly Commended Award in 2008 and CBE, Qatar University-Excellence in Research Award, 2011-2012.

Faisal Talib is a Professor at the Department of Mechanical Engineering, Zakir Hussain College of Engineering \& Technology, Aligarh Muslim University (AMU), Aligarh, (U.P.), India. He holds a PhD degree from Indian Institute of Technology, Roorkee and Masters in Industrial and Production Engineering from AMU. He has more than 20 years of teaching experience and has more than 85 publications to his credit in national/international journals and conferences. His special interest includes Quality Engineering, TQM, Service Quality, Quality Concepts, Industrial and Production Management, Operations Management, and Quality Management in Service Industries. 